\title{
Style żywieniowe Polaków i ich społeczno-demograficzne uwarunkowania
}

\author{
Nutritional styles of Poles and their socio-demographic determinants
}

\author{
Agnieszka A. Borowiec ${ }^{\bowtie}$, Anita E. Aranowska
}

Instytut Kardiologii, Zakład Epidemiologii, Prewencji Chorób Układu Krążenia i Promocji Zdrowia, ul. Alpejska 42, 04-628 Warszawa Department of Epidemiology, Cardiovascular Disease Prevention and Health Promotion, Institute of Cardiology,

$\triangle$ aborowiec@ikard.pl

\begin{abstract}
Introduction: Nutrition belongs to the modifiable risk factors for diseases and is a topic of health education. Its change may be difficult because food is not only a physiological need but is also a part of lifestyle. Lifestyle is defined as a coherent whole, including the behaviour chosen by people to the extent that allows them their place in the social structure. Different dietary practices can create clusters that are components of different lifestyles. The aim of the analysis was to identify the nutritional styles of Poles and their socio-demographic determinants.

Materials and methods: Data were acquired from a survey conducted on a nationwide representative sample $(n=1000)$ completed in 2016. Principal component analysis and multiple linear regression analysis were performed.
\end{abstract}

Results: Three nutritional styles were identified: "careless", "healthy" and "traditional". The "careless" style is typical for men, younger people and those living in larger households. It is rarely typical of professionals and managers, or pupils and students, retirees and pensioners, and residents of the smallest cities. The "healthy" style is mostly characteristic of women, those with tertiary and secondary education, students and entrepreneurs. The "traditional" style is more frequent among younger people living in smaller households, with secondary and vocational education, as well as residents of cities with a population from 50 to 200 thousand. Conclusions: The analysis indicated the existence of nutritional styles associated with position in the social structure, and this should be considered in health education related to nutrition. Keywords: nutrition; lifestyle; health education.

\begin{abstract}
ABSTRAKT
Wstęp: Sposób odżywiania należy do modyfikowalnych czynników ryzyka chorób i jest jednym z przedmiotów edukacji zdrowotnej. Jego zmiana może być trudna, ponieważ jedzenie nie tylko służy zaspokojeniu potrzeb fizjologicznych, lecz także jest elementem stylu życia, który definiuje się jako spójną całość obejmującą zachowania wybierane przez ludzi w zakresie, w jakim pozwala im na to ich ulokowanie w strukturze społecznej. Różne praktyki żywieniowe mogą stanowić elementy różnych stylów życia.

Celem analizy była identyfikacja stylów żywieniowych Polaków oraz ich społeczno-demograficznych uwarunkowań.

Materiały i metody: Dane zebrano w 2016 r. za pomocą wywiadu kwestionariuszowego bezpośredniego na ogólnopolskiej próbie reprezentatywnej $(\mathrm{n}=1000)$. Wykonano analizę głównych składowych oraz analizę regresji liniowej wielokrotnej.
\end{abstract}

Wyniki: Zidentyfikowano trzy style żywieniowe - „niedbały”, „prozdrowotny” i „tradycyjny”. Styl „niedbały” jest typowy dla mężczyzn, osób młodszych oraz ludzi żyjących w większych gospodarstwach domowych. Rzadziej cechują się nim specjaliści, wykonawcy wolnych zawodów i kierownicy, a także uczniowie i studenci, emeryci i renciści oraz mieszkańcy najmniejszych miast. Styl „prozdrowotny” charakteryzuje przeważnie kobiety, osoby z wykształceniem wyższym i średnim, uczniów i studentów, a także przedsiębiorców. Styl „tradycyjny” częściej cechuje osoby młodsze, mieszkające w mniejszych gospodarstwach domowych, z wykształceniem średnim i zasadniczym zawodowym, a także mieszkańców miast liczących 50 000-200 000 mieszkańców. Wnioski: Analiza wskazuje na istnienie stylów ży wieniowych związanych z ulokowaniem w strukturze społecznej, co powinno być uwzględniane w edukacji zdrowotnej w zakresie żywienia. Słowa kluczowe: odżywianie; styl życia; edukacja zdrowotna.

\section{WSTĘP}

Aktualne analizy stanu zdrowia społeczeństwa polskiego pokazują duże rozpowszechnienie wielu chorób żywieniowozależnych takich jak otyłość, cukrzyca, hiperlipidemia czy nadciśnienie tętnicze [1]. Jednocześnie z badań sposobu odżywiania wynika, że znaczny odsetek Polaków cechuje się niewłaściwymi zwyczajami żywieniowymi [2, 3]. Odpowiednio skomponowana dieta, bogata w warzywa i owoce, pełnoziarniste produkty zbożowe, oliwę z oliwek, nasiona roślin strączkowych, orzechy, ryby, przy jednoczesnym małym spożyciu mięsa, tłuszczów zwierzęcych oraz umiarkowanym mleka i jego przetworów, może wpływać na poprawę stanu zdrowia, a nawet prowadzić do redukcji zachorowalności na przewlekłe choroby niezakaźne oraz do zmniejszenia śmiertelności [4, 5]. Pomimo że sposób odżywiania należy do modyfikowalnych czynników ryzyka chorób i jest jednym z przedmiotów edukacji zdrowotnej, jego zmiana może być trudna, ponieważ 
jedzenie nie tylko jest aktem biologicznym służącym zaspokojeniu potrzeb fizjologicznych, lecz także jest elementem kultury. To, co się je, jak się łączy różne produkty, czy jada się z kimś (a jeśli tak, to z kim), czy też samotnie, gdzie spożywa się posiłek i w jakich godzinach - pełni funkcje symboliczne. Może wyrażać zarówno indywidualną tożsamość jednostki, jak i przynależność do grup społecznych $[6,7,8]$. Co więcej, może być związane ze zjawiskami socjologicznymi zachodzącymi w społeczeństwach rozwiniętych, takimi jak utowarowienie, globalizacja, indywidualizacja, postfordyzm, informalizacja, stylizacja i nowoplemienność [7].

Z socjologicznego punktu widzenia praktyki żywieniowe są elementem stylu życia. W naukach o zdrowiu często utożsamia się „zdrowy styl życia” z zestawem zachowań, które nie mają ze sobą nic wspólnego oprócz tego, że wpływają na zdrowie i są przedmiotem indywidualnych wyborów jednostek [9] Podobnie decyzje dotyczące spożywanych produktów i napoi, rodzajów i liczby posiłków, sposobów przygotowywania i przyprawiania potraw traktowane są jako podejmowane niezależnie od siebie i niezależne od kontekstu, w którym to się dzieje. Jednak według teorii socjologicznej styl życia jest spójną całością składającą się z zachowań, które ludzie wybierają, ale $\mathrm{w}$ takim zakresie, $\mathrm{w}$ jakim pozwala im na to ich ulokowanie w strukturze społecznej. Oznacza to, że zależy on od jednostkowych wyborów ludzi oraz ich szans życiowych - ograniczeń i możliwości determinowanych przez ulokowanie w strukturze społecznej (choices and chances) [10, 11]. Takie ujęcie zostało wykorzystane przez Cockerhama [9], który stworzył popularną w socjologii medycyny koncepcję „zdrowotnych” stylów życia (health lifestyles). Według niego są to kolektywne wzory zachowań związanych ze zdrowiem, które bazują na wyborach spośród opcji dostępnych jednostkom z uwagi na ich szanse życiowe. Wzory te obejmują działania związane ze zwyczajami żywieniowymi, piciem alkoholu, paleniem tytoniu, aktywnością fizyczną, radzeniem sobie ze stresem, odpoczynkiem, higieną osobistą oraz inne zachowania dotyczące zdrowia.

Praktyki żywieniowe są istotnymi elementami stylu życia. Wydaje się zatem, że można wyodrębnić style żywieniowe będące podtypami generalnych stylów życia, stanowiące spójne całości typowe dla określonych klas i warstw społecznych. Sugerują to rezultaty dotychczasowych badań, z których wynika, że nie tylko poszczególne zachowania związane z odżywaniem są skorelowane z cechami społeczno-demograficznymi opisującymi miejsce jednostek w strukturze społecznej, ale także całe wzory jedzenia wiążą się z przynależnością do określonych klas i warstw społecznych. Badania przeprowadzone pod koniec lat 90. XX w. i na początku XXI w. $[12,13,14]$ pokazują, że spożywanie warzyw i owoców, niezdrowych przekąsek takich jak chrupki, chipsy i słodycze oraz regularność jadania posiłków, a także preferencje wobec określonych potraw zależą od cech takich jak płeć, wiek, wykształcenie, pozycja zawodowa, miejsce zamieszkania i dochód. Z kolei np. socjologiczne analizy konsumpcji żywności we francuskim społeczeństwie wykonane przez Bourdieu [11] pokazują jej klasowy wymiar. To, jakie produkty żywnościowe jedzone i pite są najchętniej, jakie potrawy i napoje, a także w jaki sposób i z kim, zależy od gustu i stosunku do ciała, które są pochodną ulokowania w strukturze klasowej.

Celem pracy była identyfikacja stylów żywieniowych Polaków oraz ich społeczno-demograficznych uwarunkowań.

\section{MATERIAtY I METODY}

Danych do analizy dostarczyło badanie ilościowe wykonane metodą wywiadu kwestionariuszowego bezpośredniego na 1000-osobowej losowej reprezentatywnej próbie mieszkańców Polski w wieku 18 i więcej lat. Zostało ono zrealizowane jako część badania typu Omnibus w maju 2016 r. W kwestionariuszu umieszczono moduł pytań dotyczących jedzenia i picia alkoholu. Pytano m.in. o częstość jadania różnych kategorii produktów żywnościowych, pijania słodkich i energetyzujących napoi oraz alkoholu, a także o zwyczaje żywieniowe, takie jak jadanie śniadań i co najmniej trzech posiłków w ciągu dnia, dosalanie potraw oraz spożywanie gotowych dań zakupionych w sklepie. Respondenci odpowiadali, posługując się skalą odpowiedzi: codziennie, prawie codziennie (6-7 razy w tygodniu); 4-5 razy w tygodniu; 2-3 razy w tygodniu; raz w tygodniu; 2-3 razy w miesiącu; raz w miesiącu; kilka razy w roku (1-11); ani razu w ciągu roku. W celu wyodrębnienia stylów żywieniowych na podstawie odpowiedzi została wykonana analiza głównych składowych z rotacją Oblimin z normalizacją Kaisera. Liczba czynników została określona na podstawie kryterium osypiska. W celu znalezienia determinantów zidentyfikowanych stylów wykonano analizę regresji liniowej wielokrotnej (wieloczynnikowej) metodą eliminacji wstecznej- Backward (prawdopodobieństwo F wprowadzenia równe 0,01, prawdopodobieństwo F usunięcia - 0,05). Zmiennymi wyjaśnianymi były poszczególne style, a jako zmienne wyjaśniające wstawiono do modelu płeć, wiek, wykształcenie, stan cywilny, posiadanie dzieci lub wnuków, wielkość gospodarstwa domowego, dochód osobisty, wielkość miejscowości zamieszkania oraz przynależność do kategorii społeczno-zawodowej. Analiza została wykonana w programie IBM SPSS Statistics 19.

\section{WYNIKI}

Za pomocą analizy czynnikowej zidentyfikowano trzy style żywieniowe - „niedbały”, „prozdrowotny” i „tradycyjny” (tab. 1). Styl „niedbały” obejmuje częstsze jadanie słonych przekąsek takich jak chipsy, chrupki i solone orzeszki, a także ciast i słodyczy, częstsze pijanie alkoholi i słodkich lub energetyzujących napoi, dosalanie potraw oraz jadanie kupionych dań gotowych do spożycia po podgrzaniu. Na „prozdrowotny” styl żywieniowy składa się częstsze spożywanie warzyw, owoców, ryb i pieczywa razowego. Styl „tradycyjny” cechuje się regularnym jadaniem posiłków, co najmniej trzech dziennie, w tym śniadań, oraz spożywaniem z większą częstotliwością mięsa, zarówno czerwonego, jak i drobiowego.

W celu zidentyfikowania determinantów poszczególnych stylów żywieniowych wykonano trzy modele regresji liniowej 
TABELA 1. Style żywieniowe - wyniki analizy głównych składowych

\begin{tabular}{|c|c|c|c|}
\hline \multirow{3}{*}{ Jak często w ciągu ostatnich 12 miesięcy zdarzało się: } & \multicolumn{3}{|c|}{ Styl żywieniowy } \\
\hline & „niedbały” & „prozdrowotny” & „tradycyjny" \\
\hline & \multicolumn{3}{|c|}{ tadunki czynnikowe } \\
\hline Jadać słone przekąski np. chipsy, chrupki, solone orzeszki & 0,768 & & \\
\hline $\begin{array}{l}\text { Pijać słodzone napoje typu coca-cola, fanta, sprite, oranżada itp. lub } \\
\text { energetyzujące np. red bull }\end{array}$ & 0,753 & & \\
\hline Jadać zakupione w sklepie dania gotowe wymagające tylko odgrzania & 0,682 & & \\
\hline Dosalać gotowe do spożycia potrawy & 0,571 & & \\
\hline Pijać stabsze lub mocniejsze napoje alkoholowe, również w postaci tzw. drinków & 0,499 & & \\
\hline Jadać ciasta i słodycze (wyłączając cukier używany do słodzenia) & 0,461 & & \\
\hline Jadać surowe owoce & & 0,799 & \\
\hline Jadać warzywa gotowane lub surowe & & 0,766 & \\
\hline Jadać pieczywo razowe & & 0,583 & \\
\hline Jadać ryby i przetwory rybne & & 0,440 & \\
\hline Jadać co najmniej trzy positki w ciągu dnia, włączając w to śniadanie & & & 0,751 \\
\hline Jadać mięso wieprzowe, wołowe i ich przetwory, takie jak np. wędliny & & & 0,642 \\
\hline Jadać śniadania & & & 0,610 \\
\hline Jadać drób, wędliny drobiowe i inne przetwory drobiowe & & & 0,548 \\
\hline Procent wyjaśnionej wariancji & 19,0 & 15,9 & 10,1 \\
\hline
\end{tabular}

TABELA 2. Uwarunkowania stylów żywieniowych - wyniki analizy regresji liniowej wielokrotnej (wieloczynnikowej)

\begin{tabular}{|c|c|c|c|}
\hline \multirow{3}{*}{ Predyktory } & \multicolumn{3}{|c|}{ Styl żywieniowy } \\
\hline & „niedbały” & „prozdrowotny" & „tradycyjny" \\
\hline & \multicolumn{3}{|c|}{ standaryzowany współczynnik regresji wielokrotnej Beta } \\
\hline Płeć (1 - kobieta; 2 - mężczyzna) & $0,197 * *$ & $-0,169 * *$ & \\
\hline Wiek & $-0,431^{* *}$ & & $-0,117^{*}$ \\
\hline \multicolumn{4}{|l|}{ Posiadanie dzieci (1 - tak; 0 - nie) } \\
\hline \multicolumn{4}{|l|}{ Posiadanie wnuków (1 - tak; 0 - nie) } \\
\hline Wykształcenie wyższe (kat. ref. - podstawowe) & & $0,136^{\star *}$ & \\
\hline Wykształcenie średnie (kat. ref. - podstawowe) & & $0,097^{*}$ & $0,167^{* *}$ \\
\hline Wykształcenie zasadnicze zawodowe (kat. ref. - podstawowe) & & & $0,148^{* *}$ \\
\hline \multicolumn{4}{|l|}{ Osobisty dochód miesięczny netto w złotych } \\
\hline $\begin{array}{l}\text { Specjalista, osoba wykonująca wolny zawód lub kierownik } \\
\text { (kat. ref. - robotnik, pracownik fizyczny) }\end{array}$ & $-0,126^{*}$ & & \\
\hline \multicolumn{4}{|l|}{$\begin{array}{l}\text { Inny pracownik umysłowy, w tym pracownicy biurowi oraz zatrudnieni w handlu } \\
\text { i usługach (kat. ref. - robotnik, pracownik fizyczny) }\end{array}$} \\
\hline Właściciel (kat. ref. - robotnik, pracownik fizyczny) & & $0,088^{*}$ & \\
\hline \multicolumn{4}{|l|}{ Rolnik (kat. ref. - robotnik, pracownik fizyczny) } \\
\hline \multicolumn{4}{|l|}{ Niepracujący (kat. ref. - robotnik, pracownik fizyczny) } \\
\hline Uczeń lub student (kat. ref. - robotnik, pracownik fizyczny) & $-0,128^{* *}$ & $0,165^{* *}$ & \\
\hline Emeryt lub rencista (kat. ref. - robotnik, pracownik fizyczny) & $-0,146^{*}$ & & \\
\hline Wielkość gospodarstwa domowego & $0,107 * *$ & & $-0,111^{*}$ \\
\hline Zamieszkiwanie miasta powyżej 200000 mieszkańców (kat. ref. - wieś) & & & $-0,128^{* *}$ \\
\hline Zamieszkiwanie miasta 50 000-200 000 mieszkańców (kat. ref. - wieś) & & & $0,103^{*}$ \\
\hline Zamieszkiwanie miasta do 50000 mieszkańców (kat. ref. - wieś) & $-0,101^{* *}$ & & \\
\hline \multicolumn{4}{|l|}{ Stan cywilny - rozwiedziony (kat. ref. kawaler/panna) } \\
\hline \multicolumn{4}{|l|}{ Stan cywilny - wdowiec/wdowa (kat. ref. kawaler/panna) } \\
\hline Skorygowane $\mathrm{R}^{2}$ & 0,375 & 0,077 & 0,072 \\
\hline
\end{tabular}

${ }^{*} \mathrm{p} \leq 0,05 ;{ }^{* *} \mathrm{p} \leq 0,01$ 
wielokrotnej (tab. 2). Okazały się one dobrze dopasowane do danych. Cechy wprowadzone jako predyktory do wszystkich trzech modeli regresji w największym stopniu odpowiadają za styl „niedbały”, gdyż aż w 38\%, podczas gdy w wypadku stylu „zdrowego" - w ok. 8\%, a w wypadku stylu „tradycyjnego" - w ok. 7\%.

Styl „niedbały” jest typowy dla mężczyzn, osób młodszych oraz osób żyjących w większych gospodarstwach domowych. Rzadziej cechują się nim specjaliści, osoby wykonujące wolne zawody, kierownicy, uczniowie i studenci oraz mieszkańcy najmniejszych miast (do 50000 mieszkańców). Styl „prozdrowotny” charakteryzuje przeważnie kobiety, osoby z wykształceniem wyższym i średnim, uczniów i studentów, a także właścicieli firm. Styl „tradycyjny” częściej mają osoby młodsze, mieszkające w mniejszych gospodarstwach domowych, z wykształceniem średnim i zasadniczym zawodowym, a także mieszkańcy miast średniej wielkości (50 000-200 000 mieszkańców), rzadziej - mieszkańcy miast o największej liczbie mieszkańców (powyżej 200 000).

\section{DYSKUSJA}

\section{Style żywieniowe}

Dzięki analizie wyodrębnionych stylów pod względem dietetycznym wykazano, że styl „prozdrowotny” jest zdecydowanie korzystny dla zdrowia, „niedbały” - zdecydowanie niekorzystny, a „tradycyjny” zawiera elementy zarówno korzystne, jak i niekorzystne.

Korzystny dla zdrowia styl „prozdrowotny” obejmuje częste jedzenie warzyw, owoców, pieczywa razowego oraz ryb. Duży udział tych produktów $\mathrm{w}$ diecie jest elementem zasad zdrowego odżywiania [15]. Produkty te są również charakterystyczne dla diety śródziemnomorskiej rekomendowanej w prewencji chorób sercowo-naczyniowych [16]. Błonnik pokarmowy, witaminy, zwłaszcza antyoksydacyjne, minerały i nienasycone kwasy tłuszczowe dostarczone z tak skomponowaną dietą pozwalają na utrzymanie odpowiedniego poziomu lipidów, glukozy we krwi oraz ciśnienia tętniczego, co ma zasadnicze znaczenie dla powstawania przewlekłych chorób niezakaźnych. Z kolei sposób odżywiania określony jako styl „niedbały” wiąże się z wysoką kalorycznością diety, dużym udziałem łatwo przyswajalnych węglowodanów, tłuszczów (zwłaszcza nasyconych i izomerów trans nienasyconych kwasów tłuszczowych) oraz sodu. Pozostaje to w sprzeczności z obecnie obowiązującymi zaleceniami żywieniowymi [15], jak również zaleceniami dotyczącymi prewencji chorób układu sercowo-naczyniowego [17] i może prowadzić m.in. do rozwoju nadwagi, otyłości, cukrzycy typu 2, chorób układu sercowo-naczyniowego, nadciśnienia tętniczego i nowotworów [18]. Niejednoznaczny pod względem zdrowotnym jest ostatni z wyodrębnionych stylów, tj. styl „tradycyjny". Obejmuje on z jednej strony właściwe zwyczaje dotyczące posiłków, tj. codzienne jadanie śniadań oraz co najmniej trzech posiłków dziennie, a z drugiej strony - częste spożywanie mięsa, zarówno czerwonego (wołowego i wieprzowego), jak i drobiu. Zgodnie z najnowszymi rekomendacjami [15] zaleca się regularne spożywanie 4-5 posiłków dziennie, natomiast należy ograniczać konsumpcję mięsa, zwłaszcza czerwonego i przetworzonych produktów mięsnych do 0,5 kg na tydzień.

Wyodrębnione style żywieniowe mają nie tylko znaczenie zdrowotne, lecz także można je interpretować w szerszym kontekście społecznym. Jak się wydaje, „niedbały” styl żywieniowy może być elementem stylu życia skoncentrowanego na rozrywce. Wskazuje na to duża częstość spożywania słodkich i słonych przekąsek, alkoholu i słodkich napoi, które są zazwyczaj podawane jako poczęstunek podczas różnego rodzaju spotkań towarzyskich. Z kolei częste jadanie gotowych zakupionych dań i częste dosalanie gotowych potraw może świadczyć o braku czasu, a także o braku refleksji nad własną dietą. W kontekście zjawisk społecznych zachodzących w społeczeństwach rozwiniętych można interpretować ten styl jako przejaw utowarowienia jedzenia, a jednocześnie próbę jego ujednostkowienia [7]. Utowarowienie polega na traktowaniu jedzenia jako towaru dystrybuowanego przez rynek i państwo, co objawia się m.in. zwiększaniem udziału żywności zakupywanej kosztem żywności wyprodukowanej i przyrządzonej samodzielnie. Ujednostkowienie może stanowić strategię obronną przed utowarowieniem, jest próbą nadania standardowemu zakupionemu w supermarkecie daniu niepowtarzalnego wyglądu i smaku poprzez dodawanie przypraw lub innych dodatków. Oznaką utowarowienia byłoby kupowanie gotowych standardowych produktów, a ujednostkowienia - indywidualne doprawianie potraw.

Styl „prozdrowotny” obejmuje takie wybory dotyczące spożywanych produktów żywnościowych, które są eksponowane w edukacji zdrowotnej skoncentrowanej na sposobie odżywiania. Z jednej strony taki styl odżywiania może być więc efektem oddziaływania edukacji zdrowotnej, zaś z drugiej strony coraz większa koncentracja na zdrowiu, „zdrowym stylu życia” i wyglądzie ciała we współczesnych społeczeństwach jest swego rodzaju modą, szczególnie w niektórych środowiskach. Taki styl odżywiania się można interpretować także jako efekt poddania się modzie na „zdrowy styl życia” i szczupłą sylwetkę.

Styl „tradycyjny” został tak nazwany, ponieważ przedstawia tradycyjną wizję tego, co znaczy dobre odżywianie. Spożywanie co najmniej trzech posiłków dziennie, rozpoczynanie dnia śniadaniem oraz duża konsumpcja mięsa odpowiada wyobrażeniom o właściwym sposobie odżywiania się w czasach, gdy praca opierała się w głównej mierze na sile fizycznej. Choć w zaleceniach zdrowotnych nadal przykłada się wagę do systematycznego jedzenia, to tempo współczesnego życia, organizacja dnia pracy lub nauki czy zwiększenie udziału jednoosobowych gospodarstw domowych powodują pojawienie się w sferze odżywiania zjawisk zwanych informalizacją jedzenia i gastroanomią [7]. Aspektami tych zjawisk są zanikanie norm dotyczących godzin posiłków, zastępowanie zaplanowanych i specjalnie przygotowanych posiłków podjadaniem oraz nieprzestrzeganie częstotliwości jedzenia. Z kolei modernizacja prowadzi do zmniejszania się proporcji osób wykonujących zawody fizyczne i mniejszego zapotrzebowania na spożywanie mięsa. Stąd też styl żywieniowy oparty na regularności posiłków 
i dużym udziale mięsa w diecie coraz mniej przystaje do realiów współczesnego życia i może być nazwany „tradycyjnym”.

\section{Uwarunkowania stylów żywieniowych \\ Płeć}

Opisywane w literaturze różnice między kobietami a mężczyznami pod względem ich stosunku do zdrowia i praktykowanych zachowań prozdrowotnych znalazły odzwierciedlenie także w ich stylach żywieniowych. Jak wskazuje opisywane badanie, styl „niedbały” częściej charakteryzuje mężczyzn, podczas gdy „prozdrowotny” - kobiety. Jest to zgodne ze spostrzeżeniami z innych badań [19, 20, 21], z których wynika, że kobiety i dziewczęta są zorientowane bardziej prozdrowotnie w sferze żywienia, wybierają i spożywają zdrowsze produkty, bardziej zwracają uwagę na swoje zwyczaje żywieniowe niż mężczyźni, kierując się pragnieniem utrzymania dobrego wyglądu, a także mają bardziej prozdrowotną motywację.

\section{Wiek}

Analiza pokazała, że o ile młodszy wiek sprzyja raczej niezdrowym stylom żywieniowym, o tyle studiowanie i nauka wiążą się ze stylami korzystnymi dla zdrowia. Bycie młodszym okazało się związane z niekorzystnym dla zdrowia odżywianiem w stylu „niedbałym” oraz „tradycyjnym” - niejednoznacznym ze zdrowotnego punktu widzenia, podczas gdy uczenie się lub studiowanie związane jest negatywnie ze stylem "niedbałym” oraz pozytywnie ze stylem „prozdrowotnym”. Jak się wydaje, wyniki te nie muszą być sprzeczne. Osoby młodsze częściej spożywają różnego rodzaju słone i słodkie przekąski, słodzone i energetyzujące napoje i alkohol, co zapewne jest związane z ich większą aktywnością towarzyską. Dobry stan zdrowia sprawia, że perspektywa zachorowania wydaje się im odległa, a wysiłki nakierowane na poprawę czy zachowanie zdrowia zbędne. Wyniki badania wskazują, że nieco inną kategorią osób młodych są studenci. Mieszkający w dużych ośrodkach miejskich i stykający się z różnymi środowiskami studenci łatwiej niż ich rówieśnicy, którzy zakończyli edukację na niższym poziomie, przyswajają nowe idee oraz ulegają nowym trendom, np. modzie na „zdrowy styl życia” i szczupłe sprawne ciało. 0 jadaniu przez studentów zdrowych produktów decydować może także dostępność np. sałatek i owoców w stołówkach i bufetach studenckich. Z kolei uczniowie i studenci mieszkający w domach rodzinnych mogą się lepiej odżywiać, gdyż ich rodzice przykładają większą wagę do ich żywienia.

Dotychczasowe badania nie dostarczały podobnych wyników. Okazuje się, że studenci niezależnie od uczelni i kierunku studiów odżywiają się w sposób odbiegający od zaleceń, choć studentki charakteryzują się bardziej prozdrowotnymi zachowaniami żywieniowymi niż studenci [22, 23, 24, 25]. Jednak w doniesieniach tych nie porównuje się sposobu odżywiania studentów z odżywianiem innych grup ludności. Możliwe jest zatem, że chociaż studenci nie odżywiają się modelowo, to jednak ich dieta jest stosunkowo dobra na tle innych grup. Ponadto wytłumaczeniem uzyskanego wyniku mogą być powolne korzystne zmiany diety studentów, zachodzące w ostatnich latach pod wpływem edukacji zdrowotnej i mody.

\section{Sytuacja rodzina}

Takie cechy jak stan cywilny i posiadanie dzieci lub wnuków okazały się niezwiązane ze stylami żywieniowymi. Znaczenie ma jedynie wielkość gospodarstwa domowego. Członkowie mniejszych gospodarstw domowych częściej mają „tradycyjny” styl odżywiania, podczas gdy członkowie większych gospodarstw - styl „niedbały”. Styl żywieniowy „niedbały” większych gospodarstw może być związany z ich często gorszą sytuacją materialną. Chociaż w analizie uwzględniono dochód osobisty badanej osoby, to nie odzwierciedla on kondycji materialnej całej rodziny, która zależy od dochodów oraz liczby wszystkich jej członków. Z badań wynika, że w grupie osób z niskimi dochodami preferowana jest żywność o większej gęstości energetycznej, mniej prawidłowa w świetle zaleceń żywieniowych [26]. Widać zatem, że sytuacja rodzinna nie ma wielkiego wpływu na style żywieniowe Polaków.

Chociaż niektóre style żywieniowe są związane z mieszkaniem w miejscowości o określonej wielkości, to zależności te nie tworzą jakiegoś spójnego wzoru. Styl „prozdrowotny” nie jest związany z wielkością miejscowości, a styl „niedbały” charakteryzuje w najniższym stopniu mieszkańców najmniejszych miast. Fakt, że styl "tradycyjny” mają najrzadziej ludzie mieszkający w miejscowościach o największej liczbie mieszkańców, tj. powyżej 200 000, można wytłumaczyć ich szybszym tempem życia, co sprawia, że trudniej im zachować regularność posiłków.

\section{Status społeczno-ekonomiczny (wyksztatcenie, pozycja zawodowa, dochód)}

Spośród cech będących wyznacznikami statusu społeczno-ekonomicznego pozycja społeczno-zawodowa oraz wykształcenie były związane ze stylami żywieniowymi, zaś dochód osobisty nie. Okazało się, że wyższy status społeczno-ekonomiczny mierzony w taki właśnie sposób sprzyja stylom żywieniowym korzystnym dla zdrowia. Styl „prozdrowotny” jest bardziej typowy dla osób lepiej wykształconych, co jest spójne z wynikami innych badań [19]. Z kolei „niedbały” styl żywieniowy rzadziej charakteryzuje specjalistów, wykonawców wolnych zawodów oraz kierowników. Drugą kategorią unikającą stylu niedbałego żywienia są emeryci i renciści. W ich przypadku prawdopodobnie wpływa na to stan zdrowia. Styl "tradycyjny”, mający niejednoznaczny wpływ na zdrowie, częściej przejawiają osoby z wykształceniem średnim i zasadniczym zawodowym. Rzadziej się nim charakteryzują osoby z wykształceniem podstawowym, prawdopodobnie dlatego, że przeważnie są to ludzie starsi. Ponieważ często są to osoby samotne, wdowy lub wdowcy, dlatego częściej występuje u nich zjawisko zwane informalizacją posiłków, które polega na nieprzestrzeganiu pór i częstości posiłków. Natomiast osoby z wyższym wykształceniem cechują się większą świadomością zdrowotną, łatwiej poddają się nowym trendom, co może powodować ograniczanie spożycia mięsa. Informalizacja w ich wypadku może wynikać z organizacji dnia pracy, która nie pozwala na wspólne posiłki z rodziną.

Wyniki te pozostają w zgodzie z wiedzą płynącą z badań na temat klasy średniej prowadzonych zarówno w rozwiniętych 
krajach europejskich, jak i w Polsce, z których wynika, że klasa ta jest liderem w sferze zdrowego stylu życia [12, 27, 28, 29, 30, 31]. W prezentowanym badaniu stylami żywienia korzystnymi dla zdrowia w wyższym stopniu charakteryzują się kategorie społeczno-zawodowe, które można utożsamić z klasą średnią, czyli specjaliści, osoby wykonujące wolne zawody i kierownicy, a także osoby legitymujące się wyższym wykształceniem.

\section{WNIOSKI}

1. Wyodrębniono style żywieniowe związane z ulokowaniem w strukturze społecznej, co oznacza, że jadanie i pijanie różnych rodzajów żywności i napoi, kupowanie lub przyrządzanie potraw, określone sposoby przyprawiania dań, liczba i pory posiłków tworzą spójną całość. Style te są związane zapewne z innymi aspektami stylu życia.

2. Osoby z wyższym statusem społeczno-ekonomicznym, tj. o wyższym poziomie wykształcenia i wyższej pozycji zawodowej, częściej charakteryzują się stylem żywieniowym „prozdrowotnym”, a rzadziej „niedbałym”.

3. Kobiety częściej niż mężczyźni odżywiają się w stylu „prozdrowotnym”, rzadziej - „niedbałym”.

4. Edukacja zdrowotna w zakresie żywienia nie powinna być nakierowana na pojedyncze zachowania, ale powinna uwzględniać ich kontekst, tzn. inne zachowania żywieniowe składające się na dany styl żywieniowy oraz klasę czy warstwę społeczną, dla której jest on charakterystyczny.

\section{PIŚMIENNICTWO}

1. Drygas W, Bielecki W, Kozakiewicz K, Pająk A, Piotrowski W, Tykarski A, et al. Wieloośrodkowe Ogólnopolskie Badanie Stanu Zdrowia Ludności - WOBASZ. In: Kopeć G, Jankowski P, Pająk A, Drygas W, editors. Epidemiologia i prewencja chorób układu krążenia. Kraków: Medycyna Praktyczna; 2015. p. 42-56.

2. Waśkiewicz A, Szcześniewska D, Szostak-Węgierek D, Kwaśniewska M, Pająk A, Stepaniak U, et al. Are dietary habits of the Polish population consistent with the recommendations for prevention of cardiovascular disease? - WOBASZ II Project. Kardiol Pol 2016;74(9):969-77. doi: 10.5603/KP.a2016.0003.

3. Aranowska A, Waśkiewicz A, Piotrowski W.Zmiany w spożyciu żywności w okresie ostatnich 10 lat przez dorosłych mieszkańców trzech wybranych województw Polski. In: Gromadzka-Ostrowska J, editor. Metabolizm i fizjologia jako podstawy postępowania dietetycznego. Warszawa: SGGW; 2016. p. 335-44.

4. Trichopoulou A, Bamia C, Trichopoulos D. Anatomy of health effects of Mediterranean diet: Greek EPIC prospective cohort study. BMJ 2009;338:b2337. doi: 10.1136/bmj.b2337.

5. Puska P. The North Karelia Project: 30 years successfully preventing chronic diseases. Diabetes Voice 2008;53:26-9.

6. Fischler C. Food, self and identity. Soc Sci Inf 1988;27:275-92.

7. Domański H, Karpiński Z, Przybysz D, Straczuk J. Wzory jedzenia a struktura społeczna. Warszawa: Scholar; 2015.

8. Yates L, Warde A. Eating together and eating alone: meal arrangements in British households. Br J Sociol 2017;68(1):97-118. doi: 10.1111/14684446.12231.
9. Cockerham WC. The intersection of life expectancy and gender in a transitional state: the case of Russia. Sociol Health Illn 2012;34(6):943-57. doi: 10.1111/j.1467-9566.2011.01454.x.

10. Weber M. Gospodarka i społeczeństwo. Zarys socjologii rozumiejącej. Warszawa: PWN; 2002.

11. Bourdieu P. Dystynkcja. Społeczna krytyka władzy sądzenia. Warszawa: Scholar; 2005.

12. Kostka R. Zdrowy styl życia po polsku. In: Falkowska M, editor. Wartości, praca, zakupy... O stylach życia Polaków. Warszawa: CBOS; 1997.

13. Zachowania i nawyki żywieniowe Polaków. Komunikat z badań CBOS 150/2010. Warszawa: CBOS; 2010.

14. Zachowania żywieniowe Polaków. Komunikat z badań CBOS 115/2014. Warszawa: CBOS; 2014

15. Jarosz M, Rychlik E, Wierzejska R, Szczepaniak W, Gajowiak R. Sprawozdanie z I Narodowego Kongresu Żywieniowego „Żywność i żywienie w prewencji i leczeniu chorób - postępy 2015”. Żyw Człow 2016;43:7-19.

16. Estruch R, Ros E, Salas-Salvado J, Covas MI, Corella D, Aros F. Primary prevention of cardiovascular disease with Mediterranean diet. N Eng J Med 2013;368(14):1279-90.

17. Piepoli M, Hoes A, Agewall S, Albus C, Brotons C, Catapano AL, et al. 2016 European Guidelines on cardiovascular disease prevention in clinical practice: The Sixth Joint Task Force of the European Society of Cardiology and Other Societies on Cardiovascular Disease Prevention in Clinical Practice (constituted by representatives of 10 societies and by invited experts) Developed with the special contribution of the European Association for Cardiovascular Prevention \& Rehabilitation (EACPR). Eur Heart J 2016;37(29):2315-81.

18. Szostak WB, Cybulska B, Kłosiewicz-Latoszek L, Szostak-Węgierek D. Primary prevention of cardiovascular disease and other chronic noncommunicable diseases in the centre of attention of the United Nations: special importance of prudent diet. Kardiol Pol 2013;71(4):321-4. doi: 10.5603/ KP.2013.0058.

19. Wądołowska L, Babicz-Zielińska E, Czarnocińska J. Food choice models and their relations with food preferences and eating frequency in the Polish population: POFPRES study. Food Policy 2008;33:122-34.

20. Arganini C, Saba A, Comitato R, Virgili F, Turrini A. Gender differences in food choice and dietary intake in modern western societies. In: Maddock J, editor. Public health - social and behavioral health. Rijeka: InTech; 2012.

21. Imamura F, Micha R, Khatibzadeh S, Fahimi S, Shi P, Powles J, et al. Dietary quality among men and women in 187 countries in 1990 and 2010: a systematic assessment. Lancet Glob Health 2015;3(3):e132-42. doi: 10.1016/ S2214-109X(14)70381-X.

22. Myszkowska-Ryciak J, Kraśniewska A, Harton A, Gajewska D. Porównanie wybranych zachowań ży wieniowych studentek Akademii Wychowania Fizycznego i Szkoły Głównej Gospodarstwa Wiejskiego w Warszawie. Probl Hig Epidemiol 2011;92(4):931-4.

23. Gawlikowska-Sroka A, Dzięciołowska-Baran E, Szczurowski J. Ocena nawyków żywieniowych studentów polskich pierwszego roku medycyny. Pomeranian J Life Sci 2015;61(2):186-90. doi: 10.21164/pomjlifesci.77.

24. Galiński G, Czarnocińska J, Zaborowicz K, Durczewski P, Kaźmierczak P, Górska K. Ocena częstotliwości spożycia produktów spożywczych przez studentów zależnie od ich płci. Probl Hig Epidemiol 2016;97(3):251-4.

25. Zaborowicz K, Czarnocińska J, Galiński G, Kaźmierczak P, Górska K, Durczewski P. Evaluation of selected dietary behaviours of students according to gender and nutritional knowledge. Rocz Państw Zakł Hig 2016;67(1):45-50.

26. Drewnowski A, Specter SE. Poverty and obesity: the role of energy density and energy costs. Am J Clin Nutr 2004;79(1):6-16.

27. Crawford R. Healthism and the medicalization of everyday life. Int $J$ Health Serv 1980;10(3):365-88. doi: 10.2190/3H2H-3XJN-3KAY-G9NY.

28. Savage M, Barlow J, Dickens P, Fielding T. Property. Bureaucracy and culture: middle class formation in Contemporary Britain. London-New York: Routledge; 1995.

29. Ostrowska A. Styl życia a zdrowie. Warszawa: IFiS PAN; 1999.

30. Domański H. Polska klasa średnia. Wrocław: Fundacja na Rzecz Nauki Polskiej; 2002.

31. Tomlinson M. Lifestyle and social class. Eur Sociolog Rev 2003;19(1): 97-111. 